\title{
Deactivation of AMPK $\alpha /$ GSK-3 $\beta$ Leads to High-Level Glycogen Synthase in Poor Pork Meat Quality
}

\author{
Juhyun Nam ${ }^{1 *}$, Dong-Gi Lee ${ }^{1 *}$, Seung-Yeul Lee ${ }^{1}$, So-Jung Yoon ${ }^{1,2}$, Hyun Joo An ${ }^{2}$, Gap-Don Kim ${ }^{3}$, Seon-Tae Joo ${ }^{4}$, \\ Ik Soon Jang ${ }^{1}$, Hwak Rae Cho ${ }^{5}$, Sam Woong Kim ${ }^{5}$, Chul Wook Kim ${ }^{5} \&$ Jong-Soon Choi ${ }^{1,2}$ \\ ${ }^{1}$ Division of Life Science, Korea Basic Science Institute, Daejeon 305-806, Republic of Korea \\ ${ }^{2}$ Graduate School of Analytical Science and Technology, Chungnam National University, Daejeon 305-764, \\ Republic of Korea \\ ${ }^{3}$ Division of Biotechnology, College of Applied Life Sciences, Jeju National University, 66 Jejudaehakro, Jeju \\ 690-756, Republic of Korea \\ ${ }^{4}$ Department of Animal Science, Institute of Agriculture \& Life Science, Gyeongsang National University, Jinju, \\ 660-701, Republic of Korea \\ ${ }^{5}$ Swine Science and Technology Center, Gyeongnam National University of Science and Technology (GNTECH), \\ Jinju 660-758, Republic of Korea
}

Correspondence: Chul Wook Kim, Swine Science \& Technology Center, Gyeongnam National University of Science and Technology (GNTECH), Jinju 660-758, Korea. Tel: 82-55-751-3281. E-mail: cwkim@gntech.ac.kr

Jong-Soon Choi, Division of Life Science, Korea Basic Science Institute, Daejeon 305-333, Korea. Graduate School of Analytical Science and Technology, Chungnam National University, Daejeon 660-758, Korea. Tel: 82-42-865-3428. E-mail: jschoi@kbsi.re.kr

* These authors contributed equally

Received: June 18, 2013 Accepted: July 18, 2013 Online Published: August 15, 2013

doi:10.5539/jas.v5n9p168 URL: http://dx.doi.org/10.5539/jas.v5n9p168

\begin{abstract}
We investigated glycogen synthase and upstream regulatory proteins determining meat quality in porcine longissimus dorsi at $24 \mathrm{~h}$ post-mortem. The general meat quality traits of 300 muscle samples were estimated. Muscle samples were classified into two groups based on ultimate $\mathrm{pH}$ of meat $24 \mathrm{~h}$ post-mortem $\left(\mathrm{pH}_{24 \mathrm{~h}}\right)$. Muscle glycogen synthase belonging to the low $\mathrm{pH}_{24 \mathrm{~h}}$ group showed remarkably higher expression than that in the high $\mathrm{pH}_{24 \mathrm{~h}}$ group. AMP activated protein kinase (AMPK) and glycogen synthase kinase 3 (GSK-3) as negative regulators of glycogen synthase deactivated the suppression of glycogen synthase by phosphorylating Ser485 of AMPK and Ser9 of GSK-3 $\beta$. These inhibitory kinases lead to high glycogen synthase expression. These results suggest that the accumulation of glycogen by up-regulating glycogen synthase and inhibiting AMPK $\alpha$ and GSK-3 $\beta$ was rapidly converted to lactate resulting in acidic meat. This molecular clue representing acidic meat

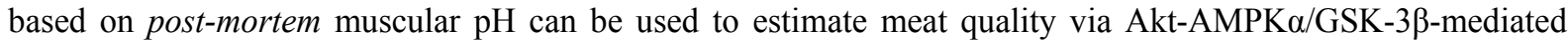
up-regulation of glycogen synthase.
\end{abstract}

Keywords: glycogen synthase, AMPK, GSK-3 $\beta$, porcine meat quality, post-mortem $\mathrm{pH}$

\section{Introduction}

Porcine meat quality is determined by various intrinsic factors such as meat color, water holding capacity (WHC), hardness, and fat content of muscle tissue (Rosenvold et al., 2001; Hocquette et al., 2005). Pale, soft, and exudative (PSE), which are poor meat qualities, are very problematic in the pork industry (Barbut et al., 2008). Severe PSE quality occurs during the early post-mortem stage and is triggered by a rapid $\mathrm{pH}$ fall and high temperature in the muscle. The pale color and WHC of meat are influenced by a number of factors including low ultimate $\mathrm{pH}$ and protein denaturation (Briskey \& Wismer-Pedersen, 1961; Warner 1997; Bowker et al., 2000; Wang et al., 2009). Thus, post-mortem muscular $\mathrm{pH}$ is a critical factor determining meat quality. In general, the final $\mathrm{pH}$ of meat is dependent on muscular glycogen content after slaughter.

Muscular glycogen is an important energy source for muscle contraction. However, fast glycogen degradation plays a major role in changes occurring in muscle post-mortem and induces the accumulation of lactic acid in 
muscle tissue (Bowker et al., 2000; Pösö \& Puolanne, 2005). The accumulation of lactic acid leads to a rapid decline in muscular $\mathrm{pH}$ known as acidic meat (referred to as poor meat quality) and vice versa during the post-mortem period, particularly during the early phase (Ryu et al., 2005). Thus, post-mortem $\mathrm{pH}$ value has a considerable effect on meat quality. In particular, the ultimate $\mathrm{pH}$ of pig muscle at $24 \mathrm{~h}$ post-slaughter $\left(\mathrm{pH}_{24 \mathrm{~h}}\right)$ is a critical factor determining meat quality traits. In addition, $\mathrm{pH}_{24 \mathrm{~h}}$ is closely related to WHC (Warner et al., 1997; Kang et al., 2010; Nam et al., 2012).

The relationship between glycogen and meat quality has been widely studied. For example, pork muscle with low glycogen and high lactate levels has a low muscular $\mathrm{pH}$ at 45 minute post-mortem (Choe et al., 2008). A rapid $\mathrm{pH}$ fall caused by accelerated glycogenolysis and ATP breakdown produces the PSE defect (Pryzbylski et al., 2006). Nevertheless, why glycogen synthases (GSs) are differentially expressed in low and high pH muscle, which refer to low and good quality meat, respectively, has not been addressed.

In this study, we evaluated pork meat quality by elucidating the molecular mechanism occurring during post-mortem metabolism. We examined the expression levels of GS and upstream regulatory proteins involved in post-mortem muscular $\mathrm{pH}$ affecting glycogen. In several studies, AMP-activated protein kinase (AMPK) has been shown to regulate muscular glycogen synthesis (Jørgensen et al., 2004). By quantitative immunoblot analysis, the expression levels of GS and regulatory proteins such as phosphorylated AMPK at Ser485 (inhibitor of GS) and Thr172 (activator of GS) and the AMPK-upstream regulator Akt were compared between low and high $\mathrm{pH}_{24 \mathrm{~h}}$ groups. Taken together, this molecular study of post-mortem muscular $\mathrm{pH}$ provides possible indicators of pork meat quality traits.

\section{Materials and Methods}

\subsection{Animals and Meat Samples}

A total of 300 Berkshire pigs were bred under the same conditions (Da-San-Genetics Co. Ltd., Namwon, Korea) and then slaughtered in 10 batches according to standard slaughtering procedures, when their body weight reached $80-90 \mathrm{~kg}$ as described previously (Kang et al., 2010). Subsequently, the samples were used for meat quality trait evaluation analyses.

\subsection{Meat Quality Evaluation}

Pork meat quality such as carcass weight, backfat thickness, $\mathrm{pH}_{24 \mathrm{~h}}$, meat color, WHC, chemical composition (collagen, fat, and protein), drip loss, cooking loss, and Warner-Bratzler shear force were evaluated. Samples of all Berkshire pigs $(n=300)$ including 133 castrations, 165 boars, and 2 sows, were divided into two groups such as the low $\mathrm{pH}$ value group $\left(\mathrm{LpH}_{24}\right.$; the lower $5 \% \mathrm{pH}_{24 \mathrm{~h}}$ of the 300 samples, $\left.n=15\right)$ and the high $\mathrm{pH}$ value group $\left(\mathrm{HpH}_{24 \mathrm{~h}}\right.$; the upper $\left.5 \% \mathrm{pH}_{24 \mathrm{~h}}, n=15\right)$.

\subsection{Glycogen and Lactate Contents Measurement}

Muscular glycogen content was measured according to Choe et al. (2008). Ten samples were randomly chosen from the $\mathrm{LpH}_{24}$ and $\mathrm{HpH}_{24}$ groups. In brief, approximately $2 \mathrm{~g}$ of muscle tissue was minced, suspended in $10 \mathrm{~mL}$ of $9 \%(\mathrm{v} / \mathrm{v})$ cold perchloric acid, and thoroughly homogenized. After centrifugation $\left(15,000 \times \mathrm{g}\right.$ at $4{ }^{\circ} \mathrm{C}$ for 20 $\mathrm{min}$ ), the supernatant was used for glycogen determination. Iodine color reagent was added to a glycogen standard. Linear regression equations of the glycogen standard for each set of samples were applied to determine glycogen concentration in the corresponding samples. Lactate content was determined spectrophotometrically (absorbance at $340 \mathrm{~nm}$ ) using a commercial kit (Boeringer, Mannheim, Germany) as described previously (Choe et al., 2008) with minor modifications. Briefly, approximately $5 \mathrm{~g}$ of muscle sample was homogenized in $20 \mathrm{~mL}$ perchloric acid $(1 \mathrm{M})$, and potassium hydroxide was added to neutralize the solution. The final volume was brought up to $10 \mathrm{~mL}$ with distilled water. Lactate concentration was measured after 20 min of refrigeration and centrifugation.

\subsection{Muscle Protein Extraction and Quantification}

Muscle tissues $(30 \mathrm{mg}$ ) were homogenized in lysis buffer purchased from iNtRON (Daejeon, Korea) according to the manufacturer's protocol. Protein concentration was quantified in triplicate using the Coomassie Dye Binding Assay (Bio-Rad, Hercules, CA, USA) employing BSA as the standard (Bradford, 1976).

\subsection{Western Blot Analysis}

Protein expression was examined by Western blot analysis according to Lee et al. (2007). We selected eight samples randomly from each $\mathrm{pH}_{24 \mathrm{~h}}$ group and subjected them to Western blot analysis. An equal amount of total protein $(30 \mu \mathrm{g})$ was separated by $12 \%$ sodium dodecyl sulfate polyacrylamide gel electrophoresis and transferred to a nitrocellulose membrane. The blotted membranes were blocked for $1 \mathrm{~h}$ in TTBS (50 mM Tris-HCl, pH 8.2, 
$0.1 \% \mathrm{v} / \mathrm{v}$ Tween 20 , and $150 \mathrm{mM} \mathrm{NaCl})$ containing $5 \%(\mathrm{w} / \mathrm{v})$ nonfat dry milk. Subsequently, the membranes were incubated overnight at $4^{\circ} \mathrm{C}$ with primary antibodies to glycogen synthase $(1: 4000$, \#3886, Cell Signaling Technology, MA, USA), AMPK $\alpha$ (1:4000, \#2532, Cell Signaling Technology, MA, USA), p-AMPK $\alpha$ (Ser485) (1:1000, \#4185, Cell Signaling Technology, MA, USA), p-AMPKa (Thr172) (1:1000, \#2531, Cell Signaling Technology, MA, USA), Akt (1:4000, \#1085-1, EPIT-MICS, CA, USA), p-Akt (Ser473) (1:1000, \#4058, Cell

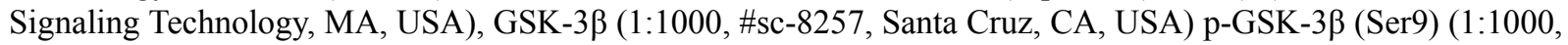
\#9336, Cell Signaling Technology, MA, USA), and GAPDH (1:6000, \#sc-25778, Santa Cruz, CA, USA). Blots were washed with TTBS and incubated with horse radish peroxidase-conjugated monkey anti-rabbit IgG secondary antibody at 1:4000 dilutions for GS, AMPKa, Akt, GAPDH, whereas 1:2000 dilution was used for both p-AMPK $\alpha$ and p-AKt. Secondary monkey anti-goat IgG antibody (1:2000, \#sc-2020, Santa Cruz, CA, USA) was used for GSK-3 $\beta$ and p-GSK-3 $\beta$. After blotting, the membranes were washed with TTBS, the immunoblot signals were detected using an enhanced chemiluminescence and visualized with a LAS-4000 (GE Healthcare, Uppsala, Sweden). GAPDH was used as an internal control. All data were analyzed using a paired Student's $t$-test, and difference with a $P$ value.

\section{Results and Discussion}

\subsection{Meat quality Evaluation in Berkshire Muscle}

Post-mortem $\mathrm{pH}$ values were measured from 300 Berkshire longissimus dorsi 24 hours after slaughter. The lowest $5 \% \mathrm{pH}$ values $\left(\mathrm{LpH}_{24}\right)$ and highest $5 \% \mathrm{pH}$ values $\left(\mathrm{HpH}_{24}\right)$ were selected based on the 24 hour post-mortem values. The mean values for the meat quality traits of the 300 Berkshires are shown in Table 1. Berkshire meat generally exhibits a high post-mortem $\mathrm{pH}$ value and WHC compared with those of other breeds, whereas drip and cooking losses are lower than those of other breeds (Suzuki et al., 2003; Lee et al., 2011). Our previous study indicated that porcine serum metabolites are clearly different between low and high $\mathrm{pH}$ groups based on the $\mathrm{pH}_{24 \mathrm{~h}}$ value of the post-mortem samples by ${ }^{1} \mathrm{H}$ nuclear magnetic resonance and high performance liquid chromatography analyses (Kim et al., 2011). Taken together with these reports, the present results indicate that $\mathrm{pH}_{24 \mathrm{~h}}$ is an important factor for evaluating meat quality.

Table 1. Characters of meat quality traits in Berkshire longissimus dorsi $(n=300)$

\begin{tabular}{lll}
\hline Trait & & Average $\pm \mathrm{SD}$ \\
\hline Carcass weight $(\mathrm{kg})$ & & $85.51 \pm 4.70$ \\
Backfat thickness $(\mathrm{mm})$ & & $24.95 \pm 5.23$ \\
$\mathrm{pH}_{24 \mathrm{~h}}{ }^{*}$ & & $5.76 \pm 0.15$ \\
& CIE $L^{* *}$ & $48.42 \pm 2.48$ \\
Meat color & $\mathrm{CIE} a^{* *}$ & $6.28 \pm 0.81$ \\
& $\mathrm{CIE} b^{* *}$ & $3.91 \pm 1.07$ \\
Water-holding capacity (\%) & & $61.31 \pm 2.10$ \\
& Collagen & $0.88 \pm 0.14$ \\
Chemical composition (\%) & Fat & $2.84 \pm 1.06$ \\
& Protein & $24.18 \pm 0.78$ \\
Drip loss (\%) & & $3.67 \pm 1.27$ \\
Cooking loss (\%) & & $23.85 \pm 4.51$ \\
Warner-Bratzler shear force (kg) & & $2.59 \pm 0.58$ \\
\hline
\end{tabular}

* The $\mathrm{pH}$ value $24 \mathrm{~h}$ after slaughter.

** CIE L, a, and b represent meat color lightness, redness, and yellowness, respectively.

We chose individual meat samples separately based on the $\mathrm{pH}_{24 \mathrm{~h}}$ corresponding to the lower $5 \%\left(n=15, \mathrm{LpH}_{24 \mathrm{~h}}\right)$ and the higher $5 \%$ group $\left(n=15, \mathrm{HpH}_{24 \mathrm{~h}}\right)$. The average $\mathrm{pH}_{24 \mathrm{~h}}$ values for the low and high $\mathrm{pH}$ groups were $5.52 \pm$ 0.02 and $6.16 \pm 0.09$, respectively $(P<0.01)$ (Figure 1 and Table 2). The $\mathrm{pH}_{24 \mathrm{~h}}$ value of $\mathrm{LpH}_{24 \mathrm{~h}}$ ranged from 5.48-5.54, whereas that for the $\mathrm{HpH}_{24 \mathrm{~h}}$ group was 6.07-6.31. Besides, middle $\mathrm{pH}_{24 \mathrm{~h}}$ group $(n=15)$ shown $5.73 \pm$ 0.0 which are ranged from 5.73-5.74. 
Table 2. Characters of meat quality traits in Berkshire longissimus dorsi groups based on $\mathrm{pH}$ value at 24 hour post-mortem corresponding to low $\mathrm{pH}_{24 \mathrm{~h}}(n=15)$ and high $\mathrm{pH}_{24 \mathrm{~h}}(n=15)$ groups

\begin{tabular}{|c|c|c|c|}
\hline \multirow{2}{*}{ Traits } & & Low $\mathrm{pH}_{24 \mathrm{~h}}$ group & High $\mathrm{pH}_{24 \mathrm{~h}}$ group \\
\hline & & Average $\pm \mathrm{SD}$ & Average $\pm \mathrm{SD}$ \\
\hline \multicolumn{2}{|l|}{ Sample number } & 15 & 15 \\
\hline \multicolumn{2}{|l|}{ Carcass weight (kg) } & $84.93 \pm 7.24$ & $86.67 \pm 3.77$ \\
\hline \multicolumn{2}{|l|}{ Backfat thickness (mm) } & $26.73 \pm 4.50$ & $27.07 \pm 5.56$ \\
\hline \multicolumn{2}{|l|}{$\mathrm{pH}_{24 \mathrm{~h}}{ }^{*}$} & $5.52 \pm 0.02$ & $6.16 \pm 0.09^{b}$ \\
\hline \multirow{3}{*}{ Meat color } & CIE $L^{* *}$ & $50.21 \pm 1.54$ & $45.17 \pm 1.71^{\mathrm{b}}$ \\
\hline & $\mathrm{CIE} a^{* *}$ & $6.68 \pm 0.74$ & $6.17 \pm 0.71$ \\
\hline & CIE $b^{* *}$ & $5.03 \pm 0.83$ & $2.60 \pm 0.59^{b}$ \\
\hline \multicolumn{2}{|l|}{ Water-holding capacity (\%) } & $60.86 \pm 2.68$ & $63.28 \pm 2.38^{\mathrm{a}}$ \\
\hline \multirow{3}{*}{ Chemical composition $(\%)$} & Collagen & $0.68 \pm 0.12$ & $0.90 \pm 0.20$ \\
\hline & Fat & $3.49 \pm 1.52$ & $3.01 \pm 0.90$ \\
\hline & Protein & $24.76 \pm 0.71$ & $23.48 \pm 0.66^{\mathrm{b}}$ \\
\hline \multicolumn{2}{|l|}{ Drip loss (\%) } & $4.66 \pm 1.33$ & $2.83 \pm 1.23^{\mathrm{b}}$ \\
\hline \multicolumn{2}{|l|}{ Cooking loss $(\%)$} & $24.56 \pm 6.26$ & $19.74 \pm 4.30^{\mathrm{a}}$ \\
\hline \multicolumn{2}{|l|}{ Warner-Bratzler shear force $(\mathrm{kg})$} & $2.71 \pm 0.67$ & $2.30 \pm 0.48$ \\
\hline
\end{tabular}

* The $\mathrm{pH}$ value $24 \mathrm{~h}$ after slaughter.

** CIE $L, a$, and $b$ represent meat color lightness, redness, and yellowness, respectively.

a, $P<0.05 ; \mathrm{b}, P<0.01$.

Lightness $(L)$ and yellowness $(b)$ of the meat samples were significantly lower in $\mathrm{HpH}_{24 h}$ group than those in the $\mathrm{LpH}_{24 \mathrm{~h}}$ group. But, redness $(a)$ was not significantly different between the two groups. WHC of meat is one of the most important properties as it affects the quality of the end meat product (Huff-Lonergan and Lonergan, 2005). WHC was higher as a percentage in the $\mathrm{HpH}_{24 \mathrm{~h}}$ group than that in the $\mathrm{LpH}_{24 \mathrm{~h}}$ group $(P<0.05)$, whereas drip loss $(\%)$ and cooking loss $(\%)$ were vice versa with a significant difference $(P<0.01)$ between the two groups.

\subsection{Quantitative Protein Comparison}

Berkshire breeds have excellent meat quality (Suzuki et al., 2003; Lee et al., 2011). The differences in the genetic effects between individuals such as single nucleotide polymorphisms have broad effects on meat quality traits (Dalvit et al., 2007; Gao et al., 2007; Williams, 2008). Proteome strategies have been attempted to understand the relationship between protein profiles and meat quality traits (Lametsch et al., 2003; Hwang et al., 2005; Kwaskborski et al., 2008; Te Pas et al., 2009). However, potential meat quality protein markers are not as well considered for evaluating as those of other meat quality traits such as genetic variations. Berkshire longissimus dorsi muscle has been used to quantitatively compare proteins between low and high $\mathrm{pH}_{24 \mathrm{~h}}$, in which the dominant expressions of Igc, Prep, Ldhb, Aco2 were identified in the $\mathrm{LpH}_{24 \mathrm{~h}}$ group by shotgun proteome analysis (Nam et al., 2012).

\subsubsection{Effect of GS on Meat Quality in Berkshire Muscle}

Post-mortem glycogenolysis has a significant effect on meat quality (Przybylisk et al., 2006). Muscle glycogen is one of the most important energy sources for muscle contraction. Glycogen degradation during the post-mortem period has a considerable effect on meat quality. The levels of glycogen and ATP decrease when oxygen is no longer available such as at slaughter and then muscle glycogen degradation during post-mortem produces lactic acid that accumulates and lowers muscle pH (Kang et al., 2010; Przybylisk et al., 2006). The analysis of enzymes related to glycogen synthesis and degradation during the post-mortem period can be a useful way to discover protein biomarkers for evaluating meat quality. 
GS (glycogen synthase, UDP-glucose-glycogen glucosyltransferase), a key enzyme in glycogen synthesis, converts glucose to glycogen (Bouskila et al., 2010). We analyzed the protein expression levels of GS between the $\mathrm{LpH}_{24 \mathrm{~h}}$ and $\mathrm{HpH}_{24 \mathrm{~h}}$ groups in 24 hour post-mortem muscle (Figure 1). GS was expressed significantly higher in $\mathrm{LpH}_{24 \mathrm{~h}}$ than in $\mathrm{HpH}_{24 \mathrm{~h}}$. The accumulated glycogen levels in $\mathrm{LpH}_{24 \mathrm{~h}}$ would be expected to be higher than that of $\mathrm{HpH}_{24 \mathrm{~h}}$ due to highly expressed GS. Consequently, $\mathrm{LpH}_{24 \mathrm{~h}}$ muscle may have produced more lactic acid than that of $\mathrm{HpH}_{24 \mathrm{~h}}$ muscle, which leads to acidic meat (know as poor meat quality) and accelerates the fall in meat $\mathrm{pH}$. Accumulation of lactic acid causes a rapid decline in muscle $\mathrm{pH}$ during the early post-mortem period (Ryu et al., 2005). These results suggest that GS can be used as a critical trait to evaluate meat quality.

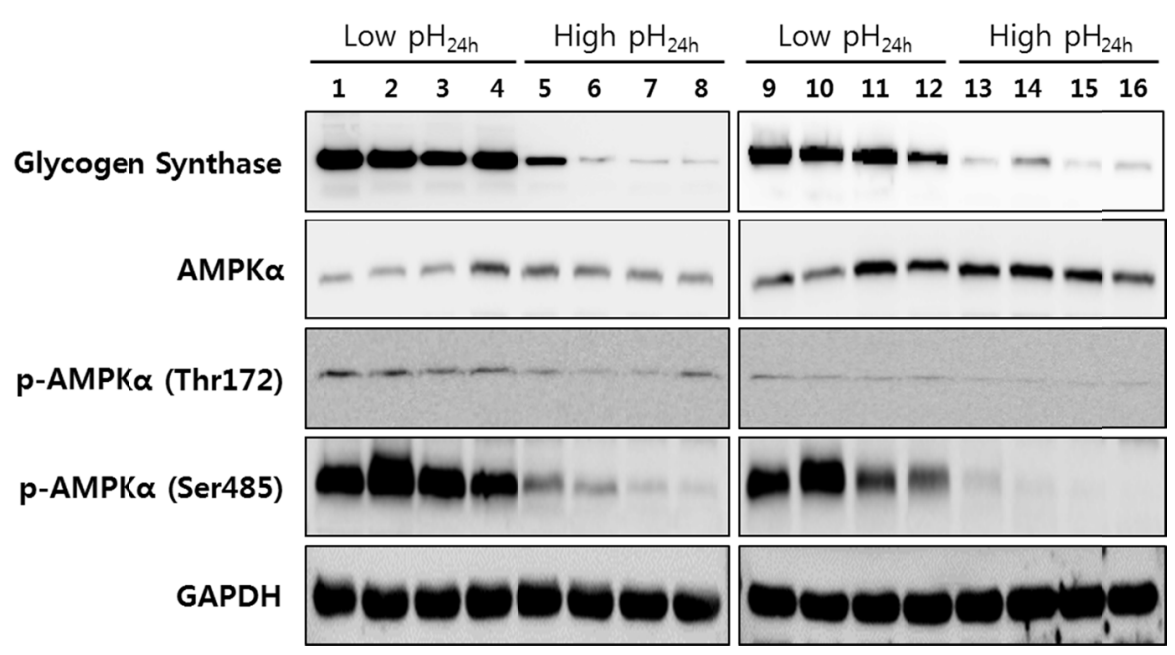

Figure 1. Western blot analysis of glycogen synthase, AMPK $\alpha$ and phospho-AMPK $\alpha$ in low and high $\mathrm{pH}$ value at 24 hour post-mortem $\left(\mathrm{pH}_{24 \mathrm{~h}}\right)$ of Berkshire longissimus dorsi. Randomly selected samples from the low and high $\mathrm{pH}_{24 \mathrm{~h}}$ groups were subjected to Western blotting to compare the expression levels of glycogen synthase,

AMPK $\alpha$, and phospho-AMPK. GAPDH was used as the control

\subsubsection{Down-Regulation of GS by p-AMPK $\alpha$ at Ser485}

AMPK is a serine-threonine kinase and a highly conserved enzyme from yeasts to animals that plays a key role in cellular energy homeostasis (Carling, 2004). AMPK is a heterotrimeric protein complex consisting of three subunits with a catalytic $\alpha$ and regulatory $\beta$ and $\gamma$ domains that together make a functional enzyme. This kinase is activated by cellular or environmental stressors such as low glucose, hypoxia, and heat shock in which AMPK can sense the decreasing ATP level in cells while increasing AMP/ATP ratios (Williams \& Brenman, 2008). Shen and coworks (2007) reported that early AMPK activation was observed in early post-mortem stage of porcine muscle in the presence of halothane gene, leading to accelerated glycolysis and increasing the incidence of PSE meat. We analyzed the protein expression level of AMPK between the $\mathrm{LpH}_{24 \mathrm{~h}}$ and $\mathrm{HpH}_{24 \mathrm{~h}}$ groups (Figure 1). The AMPK expression level was not significantly different between the two groups. AMPK inhibits GS at a low energy level (know as decreasing ATP level) under hypoxia such as the post-mortem condition.

The $\alpha$ subunit of AMPK contains several residues that can be phosphorylated. One of these residues is threonine-172, and phosphorylation at this site is essential for AMPK activity (Carling, 2004). The expression levels of AMPK $\alpha$ phosphorylated at $\mathrm{Thr} 172$ were not significantly different between the low and high $\mathrm{pH}_{24 \mathrm{~h}}$ groups (Figure 1). These results do not explain why GS was differentially expressed between $\mathrm{LpH}_{24 \mathrm{~h}}$ and $\mathrm{HpH}_{24 \mathrm{~h}}$. Next, we focused on phosphorylation at serine-485 of AMPK $\alpha$. AMPK $\alpha$ phosphorylated at Ser 485 was remarkably expressed in the $\mathrm{LpH}_{24 h}$ group compared to that in the $\mathrm{HpH}_{24 \mathrm{~h}}$ group (Figure 1). The role of phosphorylation at Ser485 is poorly understood (Horman et al., 2006). Kayampilly and Menon (2008) reported that phosphorylation of AMPK at serine residues (Ser485/491) inhibits hormonally stimulated AMPK activity. Carling (2004) suggested that phosphorylation of AMPK at Ser485 inhibits phosphorylation at Thr172 by AMP-kinase. Furthermore, AMPK phosphorylated at Ser485 has been proposed to have an inhibitory effect on AMPK activation in primary porcine aortic endothelial cells ( $\mathrm{Zu}$ et al., 2010). Together with these reports, the current results provide a clear indication that p-AMPK $\alpha$ (Ser485) plays an important role diminishing the effects of AMPK activity and GS under post-mortem conditions in porcine longissimus dorsi. 
Ten samples were randomly selected from each group and their contents were measured to evaluate the changes in glycogen and lactate (surrogate to lactic acid) contents between the low and high $\mathrm{pH}_{24 \mathrm{~h}}$ groups. No significant difference was observed in glycogen content between the two groups at $24 \mathrm{~h}$ post-mortem (Figure 2). However, the lactate content of the low $\mathrm{pH}_{24 \mathrm{~h}}$ group was significantly higher than that of the high $\mathrm{pH}_{24 \mathrm{~h}}$ group (Figure 2). Ryu et al. (2005) reported that glycogen content is not different in metabolic rate or meat quality classes at $24 \mathrm{~h}$ post-mortem. Moreover, lactate content was not different between the meat quality classes at $24 \mathrm{~h}$ post-mortem even though it is not significantly related to metabolic rate.

Accumulation of glycogen contents by highly expressed GS in the low $\mathrm{pH}_{24 \mathrm{~h}}$ group may have resulted in active degradation of glycogen, in turn, producing lactic acid, which leads to acidic meat and poor meat quality (Figures 1 and 2). Taken together with these reports, the current results provide a clear indication that GS expression could be a useful meat quality protein marker.

A

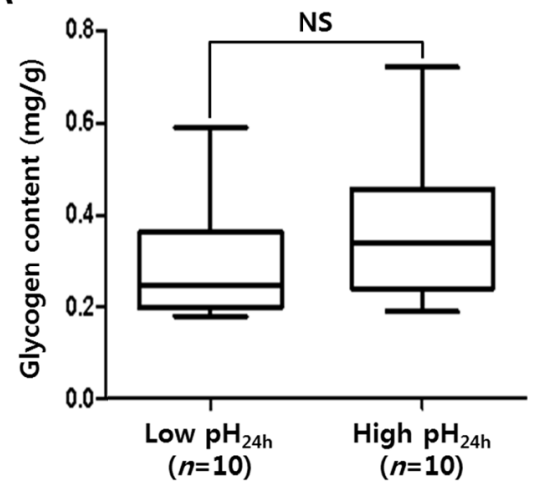

NS, not significant
B

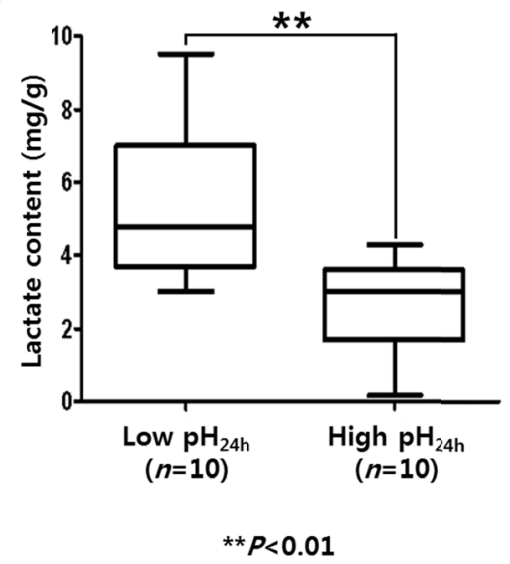

Figure 2. Glycogen and lactate contents of Berkshire longissimus dorsi in low and high pH value groups at 24 hour post-mortem $\left(\mathrm{pH}_{24 \mathrm{~h}}\right)$

\subsubsection{Down-Regulation of AMPK $\alpha$ and Glycogen Synthase Kinase $3 \beta$ (GSK-3 $)$ ) by Akt}

Akt is a serine/threonine protein kinase that plays a critical role in multiple cellular processes such as glucose metabolism, apoptosis, and transcription (Manning \& Cantley, 2007). Akt can be phosphorylated at Thr308 and Ser473 of the Akt protein itself. Three-phosphoinositide-dependent kinase 1 (PDK1) phosphorylates Thr-308 on the activation loop of the Akt kinase domain, when PDK1 binds to phosphotadylinositol-3,4,5-triphosphatate on the plasma membrane. Additionally, Akt can be phosphorylated at Ser473 on the hydrophobic motif by mammalian target of rapamycin complex 2 (Manning \& Cantley, 2007). GSK-3 is a ubiquitous serine/threonine protein kinase that negatively regulates glycogen synthesis in response to insulin (Patel et al., 2008). GSK-3 is rapidly phosphorylated in the $N$-terminal domain serine residue (Ser21 of GSK-3 $\alpha$ and Ser9 of GSK-3 $\beta$ ) on insulin or other growth factors in mammalian cells (Fang et al., 2000; Patel et al., 2008). Porcine GSK-3 $\beta$ isoforms identified from various tissues, and the effect of different isoform on GS activity were analyzed (Wang et al., 2012a). Molecular characterization of porcine GS was reported (Wang et al., 2012b). Glycogen synthase 1 (GS1) was highly expressed in the porcine skeletal muscle, and the transcription was not significantly affected by insulin treatment. However, the information on porcine GSK-3 $\beta$ and GS are still very limited. GS is well known as a direct target of GSK-3 and a regulator of cellular glucose homeostasis. Active GSK-3 phosphorylates the serine residues of GS, resulting in the inactivation of GS and subsequent reduction of glycogen synthesis.

We analyzed the protein expression levels of GSK-3 $\beta$ and phospho-GSK-3 $\beta$ at Ser9 between the $\mathrm{LpH}_{24 \mathrm{~h}}$ and $\mathrm{HpH}_{24 \mathrm{~h}}$ groups (Figure 3). GSK-3 $\beta$ was dominantly expressed at $\mathrm{LpH}_{24 \mathrm{~h}}$. Phospho-GSK-3 $\beta$ at Ser9 expression was quite different between the two groups. Similarly, Akt and phospho-Akt at Ser473 were highly expressed in $\mathrm{LpH}_{24 \mathrm{~h}}$ compared to those at $\mathrm{HpH}_{24 \mathrm{~h}}$ (Figure 3). Phospho-GSK-3 $\beta$ at Ser9 by insulin inhibited its own GSK-3 kinase activity leading to activation of GS. Serine residues of GSK-3 isoforms have been identified as targets of activated Akt, resulting in inhibition of GSK-3 activity (Sutherland et al., 1993; Halse et al., 1999). The isoforms of GSK-3 are phosphorylated and inactivated by cAMP-dependent protein kinase A (Fang et al., 2000). 
Epidermal growth factor also inhibits GSK-3 in human muscle cells (Halse et al., 1999). The lack of GSK-3 $\beta$ expression in skeletal muscle of mice results in improved glucose tolerance (Patel et al., 2008). In addition, overexpression of active Akt in transgenic mice reduces heart phospho-AMPK $\alpha$ at Thr172 (Kovacic et al., 2003). Taken together with these reports, the current results provide strong evidence that phospho-Akt (Ser473) phosphorylates both Ser485 of AMPK $\alpha$ and Ser9 of GSK-3 $\beta$, resulting in the inhibition of AMPK $\alpha$ and GSK-3 $\beta$ kinase activity followed by activation of GS to produce more glycogen under post-mortem conditions in porcine muscle (Figure 4).

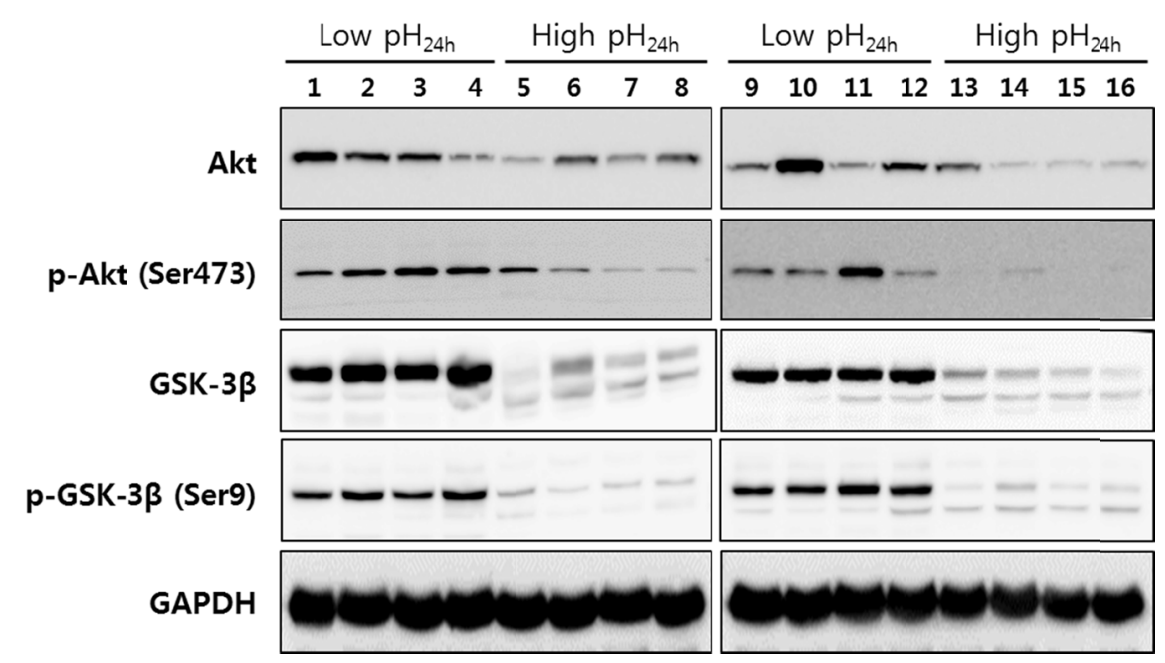

Figure 3. Western blot analysis of Akt and phospho-Akt in low and high $\mathrm{pH}$ value at 24 hour post-mortem ( $\left.\mathrm{pH}_{24 \mathrm{~h}}\right)$ of Berkshire longissimus dorsi. Randomly selected samples from low and high $\mathrm{pH}_{24 \mathrm{~h}}$ groups were subjected to

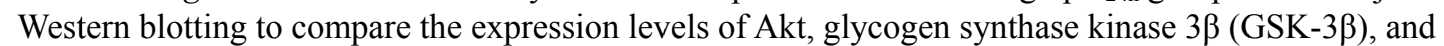
phosphorylated forms. GAPDH was used as the control

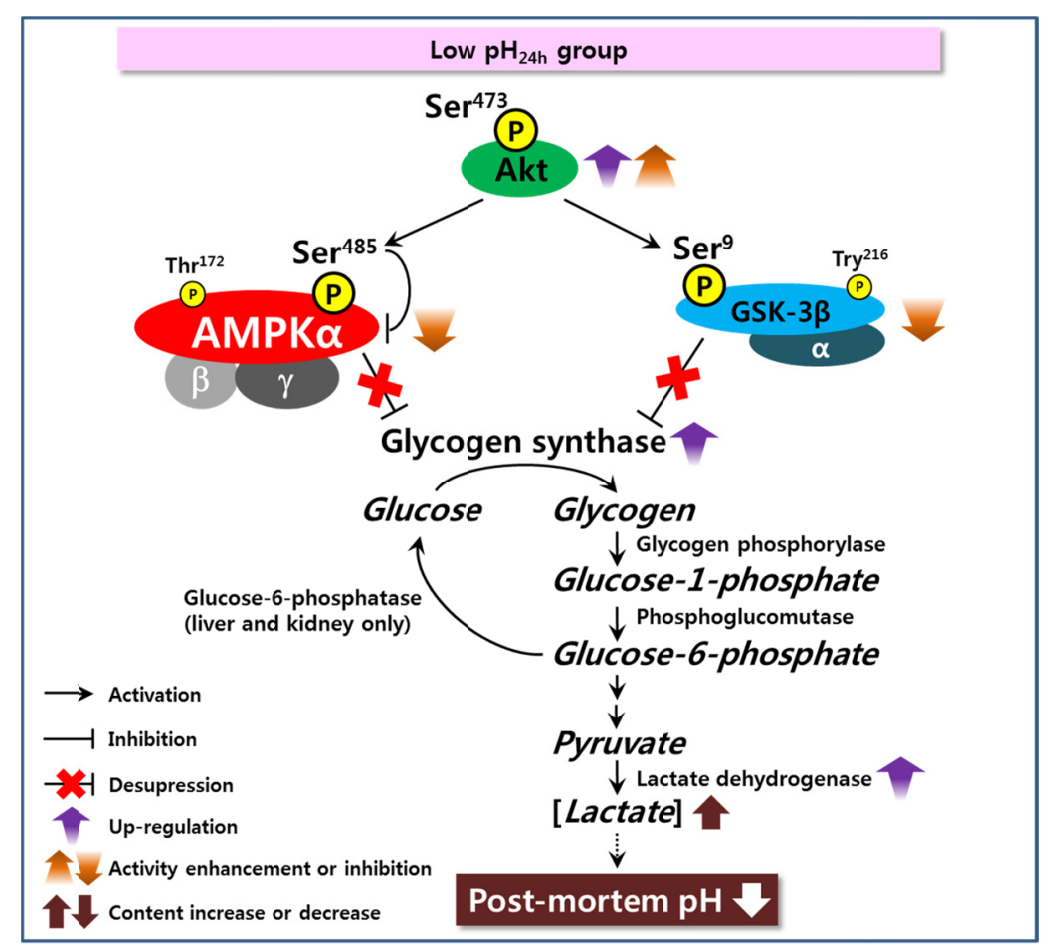

Figure 4. Molecular working model for low $\mathrm{pH}$ values at 24 hour post-mortem $\left(\mathrm{pH}_{24 \mathrm{~h}}\right)$ of post-mortem porcine muscle 
Glycogenolysis, the breakdown of glycogen to glucose-1-phosphate and glucose, is initiated by glycogen phosphorylase, and then the phosphate group is shifted to glucose-6-phosphate by phosphoglucomutase. The rate of glycogenolysis, phosphorylase activity, and lactate production rapidly increases in the perfused rat heart under anoxia, which is a surrogate to the post-mortem condition (Cornblath et al., 1963). In our previous shotgun proteomics report, lactate dehydrogenase B chain, which catalyzes the interconversion of pyruvate to lactate, was highly expressed in the low $\mathrm{pH}$ meat quality group compared to that in the high $\mathrm{pH}$ group (Nam et al., 2012). In summary, we suggest that muscle glucose was converted to glycogen by GS, followed by increased lactate concentration through glycogenolysis and glycolysis, which leads to a drop in $\mathrm{pH}$ at $24 \mathrm{~h}$ post-mortem (Figure 4).

\section{Conclusions}

Although several pork meat quality traits analyses have been conducted to analyze the metabolic rate and general proteome profile under different meat conditions, no study has investigated how they regulate GS expression under different meat conditions related to good and poor meat quality. Thus, understanding the biochemical perspective is an important issue to facilitate the signal transduction cascade analysis in different meat conditions to evaluate meat quality traits. Highly expressed GS in the low $\mathrm{pH}_{24 \mathrm{~h}}$ group suggests that accumulated glycogen produced more lactic acid leading to acidic meat. AMPK and GSK-3 are negative regulators of GS. However, phospho-Akt (Ser473) phosphorylated GSK-3 $\beta$ (Ser9) which acts as an Akt substrate and a regulatory site. This phosphorylation inactivated the kinase leading to decreased phosphorylation and activation of GS. Furthermore, phosphorylation of AMPK $\alpha$ at Ser485 and inhibition of AMPK $\alpha$ by activated Akt deactivated the suppression of GS and increased GS expression. Thus, our results suggest that glycogen synthesis occurs in a complex manner after slaughter, where the Akt-AMPK $\alpha /$ GSK- $3 \beta$ complex plays a pivotal role under different meat conditions. Although this study is an initial biochemical investigation into meat quality during the post-mortem period, we believe that this kind of study provides new insight into the biochemical mechanism and provides biochemical protein markers for meat quality evaluations, particularly for the porcine industry.

\section{Acknowledgements}

This study was supported by a Korea Basic Science Institute NAP grant (T33780). Also, this study was supported by the National Research Foundation of Korea Grant funded by the Korean Government (MEST) (2012, University-Institute cooperation program) and by grants from the Priority Research Centers Program (2011-0022965).

\section{References}

Barbut, S., Sosnicki, A. A., Lonergan, S. M., Knapp, T., Ciobanu, D. C, Gatcliffe, L. J., ... Wilson, E.W. (2008). Progress in reducing the pale, soft and exudative (PSE) problem in pork and poultry meat. Meat Science, 79, 46-63. http://dx.doi.org/10.1016/j.meatsci.2007.07.031

Bouskila, M., Hunter, R. W., Ibrahim, A. F., Delattre, L., Peggie, M., van Diepen, J. A., ... Sakamoto, K. (2010). Allosteric regulation of glycogen synthase controls glycogen synthesis in muscle. Cell Metabolism, 12, 456-466. http://dx.doi.org/10.1016/j.cmet.2010.10.006

Bowker, B. C., Grant, A. L., Forrest, J. C., \& Gerrard, D. E. (2000). Muscle metabolism and PSE pork. Journal of Animal Science, 79, 1-8.

Bradford, M. M. (1976). A rapid and sensitive method for the quantitation of microgram quantities of protein utilizing the principle of protein-dye binding. Analytical Biochemistry, 72, 248-254. http://dx.doi.org/10.1016/0003-2697(76)90527-3

Briskey, E. J., \& Wismr-Pedrsen, J. (1961). Biochemistry of pork muscles structure. I. Rate of anaerobic glycolysis and temperature change versus the apparent structure of muscle tissue. Journal of Food Science, 26, 297-302. http://dx.doi.org/10.1111/j.1365-2621.1961.tb01658.x

Carling, D. (2004). The AMP-activated protein kinase cascade-a unifying system for energy control. Trends Biochemical Science, 29, 18-24. http://dx.doi.org/10.1016/j.tibs.2003.11.005

Choe, J. H., Choi, Y. M., Lee, S. H., Shin, H. G., Ryu, Y. C., Hong, K. C., \& Kim, B.C. (2008). The relation between glycogen, lactate content and muscle fiber type composition, and their influence on postmortem glycolytic rate and pork quality. Meat Science, 80, 355-362. http://dx.doi.org/10.1016/j.meatsci.2007.12.019

Cornblath, M., Randle, P. J., Parmeggiani, A., \& Morgan, H. E. (1963). Regulation of glycogenolysis in muscle. Journal of Biological Chemistry, 238, 1592-1597.

Dalvit, C., De Marchi, M., \& Cassandro, M. (2007). Genetic tracability of livestock products: A review. Meat Science, 778, 437-449. http://dx.doi.org/10.1016/j.meatsci.2007.05.027 
Gao, Y., Zhang, R., Hu, X., \& Li, N. (2007). Application of genomic technologies to the improvement of mat quality of farm animals. Meat Science, 77, 36-45. http://dx.doi.org/10.1016/j.meatsci.2007.03.026

Fang, X., Yu, S. X., Lu, Y., Bast, R. C. Jr., Woodgett, J. R., \& Mills, G. B. (2000). Phosphorylation and in activation of glycogen synthase kinase 3 by protein kinase A. Proceedings of the National Academy of Sciences of the United States of America, 97, 11960-11965. http://dx.doi.org/10.1073/pnas.220413597

Halse, R., Rochford, J. J., McCormack, J. G., Vandenheede, J. R., Hemmings, B. A., \& Yeaman, S. J. (1999). Control of glycogen synthesis in cultured human muscle cell. Journal of Biological Chemistry, 274, 776-780. http://dx.doi.org/10.1074/jbc.274.2.776

Hocquette, J. F., Richardson, R. I., Prache, S., Medale, F., Duffy, G., \& Scollan, N. D. (2005). The future trends for research on quality and safety of animal products. Italian Journal of Animal Science, 4, 49-72.

Horman, S., Vertommen, D., Heath, R., Neumann, D., Mouton, V., Woods, A., ... Rider, M. H. (2006). Insulin antagonizes ischemia-induced $\mathrm{Thr}^{172}$ phosphorylation of AMP-activated protein kinase $\alpha$-subunits in heart via hierarchical phosphoryaltion $\mathrm{Ser}^{485 / 491}$. Journal of Biological Chemistry, 281, 5335-5340. http://dx.doi.org/10.1074/jbc.M506850200

Huff-Lonergan, E., \& Lonrgan, S. M. (2005). Mechanisms of water-holding capacity of meat: The role of postmortem biochemical and structural changes. Meat Science, 71, 194-204. http://dx.doi.org/10.1016/j.meatsci.2005.04.022

Hwang, I. H., Park, B. Y., Kim, J. H., Cho, S. H., \& Lee, J. M. (2005). Assessment of postmortem proteolysis by gel-based proteome analysis ant its relationship to meat quality traits in pig longissimus. Meat Science, 69, 79-91. http://dx.doi.org/10.1016/j.meatsci.2004.06.019

Jørgensen, S. B., Nielsen, J. N., Birk, J. B., Olsen, G. S., Viollet, B., Andreelli, F., ... Wojtaszewski, J. F. (2004). The alpha 2-5' AMP-activated protein kinase is a site 2 glycogen synthase kinase in skeletal muscle and responsive to glucose loading. Diabetes, 53, 33074-3081.

Kang, J. H., Bang, W. Y., Kwon, E. J., Lee, Y. H., Park, D. H., Cho, E. S., .. Kim, C.W. (2010). Expression of porcine myosin heavy chain 1 gene in Berkshire loins with high $\mathrm{pH}^{24}$ value. African Journal of Biotechnology, 9, 7568-7572.

Kayampilly P. P., \& Menon, K. M. J. (2008). Follicle-stimulating hormone inhibits adenosine 5 '-monophosphate-activated protein kinase activation and promotes cell proliferation of primary granulose cells in culture through an Akt-dependent pathway. Endocrinology, 150, 929-935. http://dx.doi.org/10.1210/en.2008-1032

Kim, A. R., Park, S. H., Nam, J. H., Kwon, J., Park, M. H., Kwon, S. O., ... Choi, J. S. (2011). Determination of free amino acids of porcine serum responsible for the meat quality by 1H NMR and HPLC analyses. African Journal of Biotechnology, 10, 142-09-14217.

Kovacic, S., Soltys, C. L. M., Barr, A. J., Shiojimas, I., Walsh, K., \& Dyck, J. R. B. (2003). Akt activity negatively regulates phosphorylation of AMP-activated protein kinase in the heart. The Journal of Biology Chemistry, 278, 39422-39427. http://dx.doi.org/10.1074/jbc.M305371200

Kwasiborski, A., Sayd, T., Chambon, C., Santé-Lhoutellier, V., Rocha, D., \& Terlouw, C. (2008). Pig Longissimus lumborum proteome: Part II: Relationships between protein content and met quality. Meat Science, 80, 982-996. http://dx.doi.org/10.1016/j.meatsci.2008.04.032

Lametsch, R., Karlsson, A., Rosenvold, K., Andersen, H. J., Roepstorff, P., \& Bendixen, E. (2003). Postmortem proteome changes of porcine muscles related to tenderness. Journal of Agricultural and Food Chemistry, 51, 6992-6997. http://dx.doi.org/10.1021/jf034083p

Lee, D. G., Ahsan, N., Lee, S. H., Kang, K.Y., Bahk, J. D., Lee, I. J., \& Lee, B. H. (2007). A proteomic approach in analyzing heat-responsive proteins in rice leaves. Proteomics, 7, 3369-3383. http://dx.doi.org/10.1002/pmic.200700266

Lee, Y. H., Kwon, E. J., Cho, E. S., Park, D. H., Kim, B. W., Park, H. C., ... Kim, C. W. (2011). Association analysis of polymorphism in KIAA1717, HUMMLC2B, DECR1 and FTO genes with meat quality traits of the Berkshire breed. African Journal of Biotechnology, 10, 5068-5074.

Manning, B. R., \& Cantley, L. C. (2007). AKT/PKB signaling: Navigating downstream. Cell, 129, $1261-1274$. http://dx.doi.org/10.1016/j.cell.2007.06.009 
Nam, J., Lee, D. G., Kwon, J., Choi, C. W., Park, S. H., Kwon, S. O., ... Kim, C.W. (2012). Comparative proteome analysis of porcine longissimus dorsi on the basis of $\mathrm{pH} 24$ of post-mortem muscle. Journal of Agricultural Science, 4, 48-56. http://dx.doi.org/10.5539/jas.v4n9p48

Patel, S., Doble, B. W., MacAulay, K., Sinclair, E. M., Drucker, D. J., \& Woodgett, J. R. (2008). Tissue-specific role of glycogen synthase kinase $3 \beta$ in glucose homeostasis and insulin actin. Molecular and Cellular Biology, 28, 6314-6328. http://dx.doi.org/10.1128/MCB.00763-08

Pösö, A. R., \& Puolanne, E. (2005). Carbohydrate metabolism in meat animal. Meat Science, 70, 423-434. http://dx.doi.org/10.1016/j.meatsci.2004.12.017

Przybylski, W., Monin, G., Kocwin-Podsiadta, M., \& Krzecio, E. (2006). Glycogen metabolism in muscle and its effects on meat quality in pigs - A mini review. Polish Journal of Food and Nutrition Science, 15, 257-262.

Rosenvold, K., Petersen, J. S., Lærke, H. N., Jensen, S. K., Therkildsen, M., Karlsson, A. H., ... Andersen, H. J. (2001). Muscle glycogen stores and meat quality as affected by strategic finishing feeding of slaughter pigs. Journal of Animal Science, 79, 382-391.

Ryu, Y. C., Choi, Y. M., \& Kim, B. C. (2005). Variations in metabolite contents and protein denaturation of the longissimus dorsi muscle in various porcine quality classifications and metabolic rates. Meat Science, 71, 522-529. http://dx.doi.org/10.1016/j.meatsci.2005.04.034

Shen, Q. W., Underwood, K. R., Means, W. J., McCormick, R. J., \& Du, M. (2007). The halothane gene, energy metabolism, adenosine monophosphate-activated protein kinase, and glycolysis in postmortem pig longssimus dorsi muscl. Journal of Animal Science, 85, 1054-1061. http://dx.doi.org/10.2527/jas.2006-114

Sutherland, C., Leighton, I. A., \& Cohen, P. (1993). Inactivation of glycogen synthase kinase-3 beta by phosphorylation: new kinase connections in insulin and growth-factor signaling. Biochemical Journal, 296, 15-19.

Suzuki, K., Shibata, T., Kadowaki, H., Abe, H., \& Toyoshima, T. (2003). Meat quality comparison of Berkshire, Duroc and crossbred pigs sired by Berkshire and Duroc. Meat Science, 64, 35-42. http://dx.doi.org/10.1016/S0309-1740(02)00134-1

Te Pas, M. F., Jansen, J., Broekman, K. C., Reimert, H., \& Heuven, H. C. (2009). Postmortem proteome degradation profiles of longissimus muscle in Yorkshire and Duroc pigs and their relationship with pork quality traits. Meat Science, 83, 744-751. http://dx.doi.org/10.1016/j.meatsci.2009.08.030

Warner, R. D., Kauffman, R. G., \& Greaser, M. L. (1997). Muscle protein changes post mortem in relative to pork quality traits. Meat Science, 45, 339-352. http://dx.doi.org/10.1016/S0309-1740(96)00116-7

Wang, H., Pato, M., Pietrasik, Z., \& Shand, P. (2009). Biochemical and physicochemical properties of thermally treated natural actomyosin extracted from normal and PSE pork Longissimus muscle. Food Chemistry, 113, 21-27. http://dx.doi.org/10.1016/j.foodchem.2008.06.084

Wang, L., Zuo, B., Xu, D., Ren, Z., Zhang, H., Li, X., ... Xiong, Y. (2012a). Alternative splicing of the porcine glycogen synthase kinase $3 \beta$ (GSK-3 $\beta$ ) gene with differential expression patterns and regulatory functions. PLoS ONE, 7, e40250. http://dx.doi.org/10.1371/journal.pone.0040250

Wang, L., Xiong, Y., Zuo, B., Lei, N., Ren, Z., \& Xu, D. (2012b). Molecular and functional characterization of glycogen synthase in the porcine satellite cell under insulin treatment. Molecular and Cellular Biochemistry, 360, 169-180. http://dx.doi.org/10.1007/s11010-011-1054-4

Williams, J. (2008). Genetic control of meat quality traits. Meat Biotechnology, Part I, 21-60. http://dx.doi.org/10.1007/978-0-387-79382-5_2

Willimams, T., \& Brenman, J. E. (2008). LKB1 and AMPK in cell polarity and division. Trends in Cell Biology, 18, 193-198. http://dx.doi.org/10.1016/j.tcb.2008.01.008

Zu, Y., Liu, L., Lee, M. Y. K., Xu, C., Liang, Y., Man, R. Y., ... Wang, Y. (2010). SIRT1 promotes proliferation and prevents senescence through targeting LKB1 in primary porcine aortic endothelial cells. Circulation Research, 106, 1384-1393. http://dx.doi.org/10.1161/CIRCRESAHA.109.215483 


\section{Copyrights}

Copyright for this article is retained by the author(s), with first publication rights granted to the journal.

This is an open-access article distributed under the terms and conditions of the Creative Commons Attribution license (http://creativecommons.org/licenses/by/3.0/). 